\title{
POPULATION PATTERN AND HOUSEHOLD WASTE MANAGEMENT PRACTICES IN RELATION TO BIO-PHYSICOCHEMICAL WATER QUALITY CHARACTERISTICS IN THE NAGA RIVER
}

\author{
Mariel R. Estrella \\ School of Graduate Studies, \\ Partido State University
}

Article DOI URL: https://doi.org/10.36713/epra6684

DOI NO: 10.36713/epra6684

\begin{abstract}
Rapid population growth and urbanization over the years has put pressure on natural resources threatening various fragile ecosystems. Naga river in the Philippines became a mute witness to the adverse effects of human activities on its waters. The present study took into account the waste management practices of households along the Naga river to elucidate its relation to the bio-physicochemical state of the river. The comparative analysis of water quality assessment data indicates that there is an observable deterioration of water quality due to its decreased level of Dissolved Oxygen (DO) and above normal pH level. This can be attributed to the continued practice of the households of throwing and discharging $34 \%$ and $78 \%$ of their solid and liquid wastes, respectively, directly into the river. However, there is a trend of improvement in the Naga river's water quality in terms of other parameters. The study also revealed that the size of built up areas and the household population along the Naga river is not necessarily proportional. Land use and the large household population along the Naga river was found to have higher adverse impacts on the water quality and current state of the Naga river.
\end{abstract}

KEYWORDS: Naga River, water quality, waste management, community survey

\section{INTRODUCTION}

Naga City, situated 377 kilometers south-east of Manila in the Philippines, is considered the Bicol region's commercial, financial, educational, religious, and cultural center. It is the most populous city in the area, as well as the densest. The Naga river traverses the city center. It stretches about 2.8 kilometers winding through 11 of the 27 barangays of the city.

The Department of Environment and Natural Resources Regional Office V (DENR-ROV, 2014) reports that most of the population uses the river for agricultural purposes such as irrigation of fields and propagation of fish and other aquatic resources. It also supplies water for the manufacturing industry and facilitates the transport of people and products. However, the report also noted that the river serves as discharge points for residents living near and along the river. At most points, the riverbank easement has been grossly encroached by urban dwellings and infrastructure, and as such, domestic and industrial waste and sewerage pollute the river. According to Nkwocha et al. (2004), unsanitary disposal of solid waste provides harborage for disease vectors, causes the emission of odor and environmental nuisance, and defaces urban habitations, and particularly pollutes nearby surface water.

The decay of Naga City's riverine ecology is one of the more visible problems as it affects most of the urban areas. The pollution of the Naga river could also be traced to its network of natural waterways within the city and its tributaries in Mt. Isarog. A CARE/WWF study in 2005, reported severe erosion levels in Mt. Isarog's foot slopes with increased surface run-off from vegetation/forest loss due to encroachment of agriculture from proximate barangays. Apparently, the turbid waters of the Naga river in the downstream is a result of sedimentation from severe erosion. It is particularly critical to note that the Naga river links with the Bicol river and drains to San Miguel bay, a fishing ground for municipal sustenance. With all the urban wastes and sediments/particulates draining to the downstream (Bicol River) municipalities and San Miguel Bay, it would not be surprising that fish catch has dramatically declined. Likewise, it would be noted that the system boundaries of the affected landscape cuts across three ecosystems: forest ecosystem (Mt. Isarog National Park), riverine and estuarine ecosystems (Naga and Bicol Rivers), and marine ecosystem (San Miguel Bay).

In such a context, the study provided an opportunity to understand the pivotal role of an urban environment relative to the water quality of the river. The study identified the solid and liquid waste management practices of the households living along the Naga River to elucidate its relation to the bio-physicochemical state of the river.

\section{MATERIALS AND METHODS \\ Description of the Study Area}

The study focused on the nine barangays along the Naga River, which were chosen based on land area. This included the upstream barangay Balatas, midstream barangays Penafrancia, Dayangdang, Lerma, San Francisco, and Tinago, and downstream barangays Mabolo, Sabang, and Tabuco. All are classified as 
urban areas with the majority of the land allocated to residential, commercial, and agricultural uses.

\section{Data Analysis of Waste Management Practices}

A community survey including 110 respondents from the nine barangays was conducted to obtain data on solid and liquid waste management practices of households along Naga River. To validate the responses, Focus Group Discussions (FGDs) were carried out. A total of 79 respondents composed of barangay officials and sectoral representatives like health, business and industry, academe, transport, and senior citizens participated in the FGDs. Further validation was done through Key Informant Interviews (KIIs) with 19 government officials, barangay officers, and residents along the riverbank. Both descriptive and quantitative statistics were used in the data analysis.

\section{Water Quality Parameters and Analysis}

The study made use of the dataset from the water quality assessment program of the DENR-V and ENRO-Naga City, specifically in 2002, 2006, and 2009. The 22 sampling stations covering the entire stretch of the river were chosen according to their accessibility and strategic location. A comparative analysis was done using the data on the following parametric indicators: (1) Dissolved Oxygen (DO, $\mathrm{mg} / \mathrm{L}$ ); (2) Biological Oxygen Demand (BOD, mg/L); (3) $\mathrm{pH}$ level; (4) Total Suspended Solids (TSS, mg/L); and (5) Temperature $\left({ }^{\circ} \mathrm{C}\right)$.

Aquatic life as a water quality indicator was also investigated in the study. Researchers were able to obtain and analyze data on fish species present in the waters of Naga river through the KIIs.

\section{RESULTS AND DISCUSSION Socio-demographic profile of the riverside barangays}

Out of the 7,907 households in all the nine barangays along the Naga river, only 525 or $6.64 \%$ are located directly on the banks of the river. This could be translated into a population of 2,751 based on the average household size of 5.24 [National Statistics Office (NSO), 2010]. Barangay Penafrancia, which has the highest number of households along the river, has a translated population of 775.52 or $28 \%$ of the total population along the Naga river.

As indicated in the Naga City Comprehensive Development Plan (2012), the total population of Naga City in 2000 was 137,810, and this increased to 174,931 in 2010 . This meant a population growth of $26.9 \%$ or an average of $2.41 \%$ compounded annually. The same source asserted that the projected population of Naga City by 2015 would be about 195,803 considering the $2.28 \%$ population growth rate.

Similarly, the population along the Naga River will tend to increase by the same rate of $2.28 \%$ annually. Based on the data, the total population of the nine barangays along the Naga River totals to 41,937 this can increase to about $46,717.818$ or a total population of 8,915 by 2015 . Further, the total number of household population along the riverside will also increase from 525 households to about 584.85 by 2015 .

The current population density of the city is about 1,900 residents per square kilometers or 19 residents per hectare (ha). This makes Naga City as the most densely populated city in the Bicol Region. Barangay Tabuco occupies the largest total land area along the Naga River but has a household density of 7.395 households/ha as against that of barangay Penafrancia whose household density is 86 households/ha. This implies that increased household density is a factor of urbanization and land use rather than the size of the river area. The barangay may have a large riverside area, but its land use is agricultural. Therefore there are fewer households in the area. Likewise, this result may be due to the City's Land Use Plan of 2000, where it had proposed the conversion of barangay Penafrancia from agricultural to residential land while maintaining barangay Balatas as a farming area.

In terms of income source, people living along the Naga River could be categorized into three as those with 1) fixed income from salaries and wages (government and private employment), 2) from business activities (self-employment), agricultural activities (farming and fishing), and 3) from other sources of income (padyak drivers, laborers).

Survey results show that $57 \%$ of the respondents who are living along the riverbank derive their income from government and private employment. Of those with business activities/self-employed, 38\% get their income from small to large scale businesses, and $4 \%$ derive income from farming and fishing. The result further shows that almost all (95\%) of the respondents are engaged in non-agricultural and entrepreneurial activities.

The data strongly conform to the findings of CDP (2012) which reported that "Naga has a primarily trading and service-driven economy. The service sector employs the bulk of the city's labor force, accounting for $71 \%$ of the total. The secondary and infrastructure sector (manufacturing, utilities and construction at 14\%) and others (agriculture and government 15\%) account for the rest."

Moreover, the data imply that majority of the respondents are economically active which means they are capable of supplying labor for the production of goods and services over some time [International Labour Organization (ILO), 2012].

The above result is supported by the data from NSO in 1997 which reported that "in Naga, close to $49 \%$ of the households depend on wages and salaries from nonagricultural activities, and $28 \%$ derive their income from non-agricultural entrepreneurial activities. A minimal of $7 \%$ derived income from agricultural entrepreneurial activities and 5\% from wages and salaries from such agricultural activities. It is important to note that only $11 \%$ rely on remittances, pension, retirement and sale of a lot." However, the same result is seen at the different view in the study of Pasion (2012) which indicated that "the economy of Naga City is heavily dependent on tourism and the city is a major pilgrimage site with the famous Penafrancia river procession held every September." 


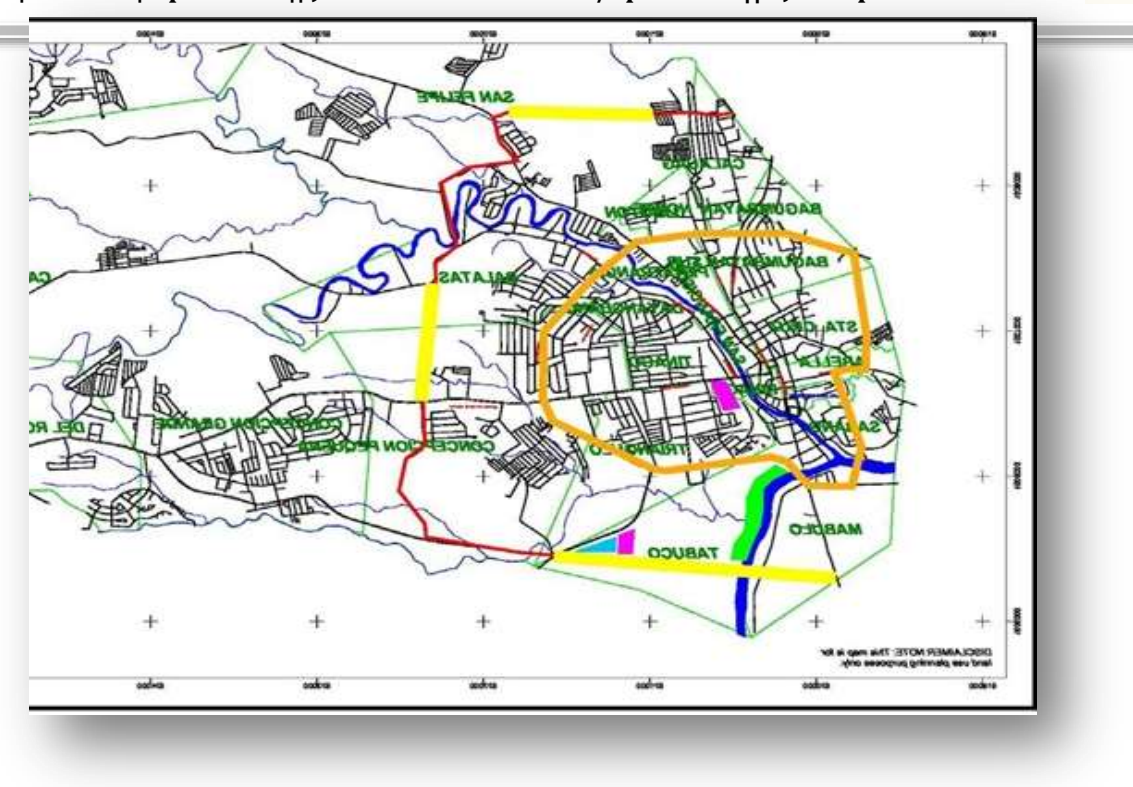

\section{Waste management practices in the site}

In terms of solid waste disposal practices of households along Naga river, data revealed that $66 \%$ of the respondents place their wastes on garbage bags and have them collected by the city government through its garbage trucks. Among the nine barangays, Tinago has the highest number of households doing this practice (83\%), while Dayangdang has the lowest at $38 \%$. Both are midstream barangays.
However, it was found out that all the households in the nine barangays still throw some of their solid wastes into the river and someplace else. This practice is most evident in Sabang, where about $23 \%$ of the households admitted to throwing their solid wastes into the river. On the other hand, households in Penafrancia are throwing their wastes anywhere, which eventually ends up to the river. Pasion (2007) affirmed that the dwellers along the riverbanks do not have proper waste disposal for both solid and liquid wastes, thereby polluting the river.

Table 1. Solid waste disposal practices of the households along the Naga River.

\begin{tabular}{|c|c|c|c|c|c|c|c|}
\hline \multirow[b]{2}{*}{ Barangay } & \multicolumn{7}{|c|}{ Disposal practices } \\
\hline & $\begin{array}{c}\text { Pick- } \\
\text { up by } \\
\text { truck } \\
(\%)\end{array}$ & $\begin{array}{c}\text { Household } \\
\text { segregate } \\
\text { solid } \\
\text { wastes } \\
(\%)\end{array}$ & $\begin{array}{c}\text { Burning } \\
\text { (\%) }\end{array}$ & $\begin{array}{c}\text { Composting } \\
\text { (\%) }\end{array}$ & $\begin{array}{c}\text { Throw } \\
\text { them in } \\
\text { the Naga } \\
\text { City River } \\
(\%)\end{array}$ & $\begin{array}{c}\text { Throw } \\
\text { away } \\
\text { anywhere } \\
(\%)\end{array}$ & $\begin{array}{c}\text { Total } \\
\text { (\%) }\end{array}$ \\
\hline PEÑAFRANCIA & 45 & 30 & 2 & 0 & 5 & 18 & 100 \\
\hline BALATAS & 65 & 20 & 5 & 3 & 5 & 2 & 100 \\
\hline DAYANGDANG & 38 & 25 & 20 & 5 & 2 & 10 & 100 \\
\hline DINAGA & 75 & 5 & 5 & 5 & 10 & 0 & 100 \\
\hline LERMA & 76 & 21 & 1 & 0 & 0 & 2 & 100 \\
\hline SABANG & 72 & 1 & 1 & 1 & 23 & 2 & 100 \\
\hline SAN FRANCISCO & 60 & 5 & 20 & 3 & 1 & 11 & 100 \\
\hline TABUCO & 80 & 9 & 1 & 1 & 5 & 4 & 100 \\
\hline TINAGO & 83 & 10 & 0 & 1 & 3 & 3 & 100 \\
\hline Average & 66 & 14 & 6.11 & 2.11 & 6 & 5.80 & 100 \\
\hline
\end{tabular}

Likewise, few households practise composting and burning solid wastes. In Dayangdang and San Francisco, about $20 \%$ of the respondents said they burn their solid wastes while $5 \%$ in Dinaga said they do compost. It can also be noted that a few households along the Naga river practice solid waste segregation at source. The Cities Development Initiative for Asia (CDIA) in 2012 reports that the City Government solid waste collection system includes waste segregation at the source, in material recovery facilities (MRF) or, after collection, by waste pickers working on the existing dumpsite in Balatas. This is to ensure that waste segregation is done regardless of the point source.

Data from the Naga City Comprehensive Development Plan 2011-2012 indicated that the garbage collection by the city government over the last three years has decreased substantially, from 72,275 tons in 2008 to 48,009 tons in 2009 and recently to only 20,767 for 2010 - an average annual reduction of $36 \%$ over the last two years. Accordingly, this may be attributed to the decentralized approach of waste segregation at the barangay, subdivision, and institutional levels, reducing volume being processed at the Balatas MRF. 
As such, this study shows that there are about $12 \%$ of solid wastes generated by the households along the Naga River that were not picked up by the garbage truck, hence did not reach the MRF. Unfortunately, indications show that they were thrown in the river.
Furthermore, the study proved that the usual practice of throwing some of the solid wastes into the river generated by the households along the Naga River is not entirely changed by the seemingly efficient garbage collection of the Naga City government.

Table 2. Sewage disposal practices of households along the Naga River.

\begin{tabular}{|c|c|c|c|c|c|c|}
\hline \multirow[b]{2}{*}{ Barangay } & \multicolumn{2}{|c|}{ Toilet Sewage disposal } & \multirow[b]{2}{*}{$\begin{array}{l}\text { Total } \\
(\%)\end{array}$} & \multicolumn{2}{|c|}{$\begin{array}{c}\text { Kitchen sewage disposal } \\
\text { (wash water) }\end{array}$} & \multirow[b]{2}{*}{$\begin{array}{l}\text { Total } \\
(\%)\end{array}$} \\
\hline & $\begin{array}{c}\text { Water- } \\
\text { sealed } \\
\text { toilet with } \\
\text { septic tank } \\
(\%)\end{array}$ & $\begin{array}{c}\text { Open-pit } \\
\text { toilet with } \\
\text { drainage } \\
(\%)\end{array}$ & & $\begin{array}{c}\text { Sink } \\
\text { drainage } \\
\text { direct to the } \\
\text { septic tank } \\
(\%)\end{array}$ & $\begin{array}{c}\text { Sink } \\
\text { drainage } \\
\text { direct to the } \\
\text { Naga City } \\
\text { river (\%) }\end{array}$ & \\
\hline PEÑAFRANCIA & 96 & 4 & 100 & 30 & 70 & 100 \\
\hline BALATAS & 80 & 20 & 100 & 70 & 30 & 100 \\
\hline DAYANGDANG & 0 & 0 & 0 & 10 & 90 & 100 \\
\hline DINAGA & 100 & 0 & 100 & 70 & 30 & 100 \\
\hline LERMA & 99 & 1 & 100 & 2 & 98 & 100 \\
\hline SABANG & 0 & 0 & 0 & 5 & 95 & 100 \\
\hline SAN FRANCISCO & 100 & 0 & 100 & 0 & 100 & 100 \\
\hline TABUCO & 100 & 0 & 100 & 0 & 100 & 100 \\
\hline TINAGO & 100 & 0 & 100 & 10 & 90 & 100 \\
\hline Average & 75.00 & 2.80 & 77.80 & 21.89 & 78.11 & 100 \\
\hline
\end{tabular}

On the other hand, household liquid waste was classified into toilet sewage and kitchen sewage. To dispose of their toilet sewage, $75 \%$ of the respondents have and use a water-sealed toilet with a septic tank. In comparison, about $2.80 \%$ have an open-pit toilet which has drainage in the river.

Moreover, the survey shows that most of the households' kitchen sink (78.11\%) drains directly to the Naga river. This means that their kitchen sewage/wash water eventually ends up in the river.

To some extent, the survey results concur with Naga City's ecological profile in 2012 that water-sealed toilet facilities were used by $95.70 \%$ of the households. The remaining $2.70 \%$ do not have any toilet facility, while $1.50 \%$ were using a closed pit (Antipolo type) toilet facility.

The City Planning and Development Office (CPDO) in 2012 argues that very few houses had septic tanks before the city introduced an ordinance that required households to have septic tanks. Only $20 \%$ likely have proper septic tanks, and the rest are simple pits then. It must also be assumed that a lot of the existing septic tanks and sanitary pits are in bad condition.

In such condition, the effluent seeps into the soil or finds its way through the drainage into the Naga River. This is further strengthened by Pasion (2007), who stated that the illegal dwellers along the riverbanks do not have proper waste disposal for both solid and liquid wastes.

The result further revealed that households in barangays Dayangdang and Sabang have no toilet sewage disposal at all. This implies that the households along the Naga River in these barangays directly disposed their toilet sewage to the river. Critical data show that $100 \%$ of the households along the Naga River in barangays San Francisco and Tabuco; 98\% in Lerma, $95 \%$ in Sabang had their sink drainage direct to the Naga River.

\section{Water quality of Naga river}

Dissolved Oxygen (DO) is the most critical indicator of the health of a water body. High levels of DO in water means an increased capacity to support a balanced aquatic ecosystem of plants and animals. Water bodies with organic (oxygen-consuming) pollutants deplete the dissolved oxygen and may lead to marine organisms' death.

Data from 2006 to 2009 show that DO have dramatically decreased below the minimum standard of $5 \mathrm{mg} / \mathrm{L}$ in sampling station numbers 1 (Tabuco Bridge), 2 (Panganiban Bridge), 3 (Colgante Bridge), and 4 (Magsaysay Bridge). The present study noted that the lowest level of DO at $3.0 \mathrm{mg} / \mathrm{L}$ and the highest biological/biochemical oxygen demand (BOD) at 11.6 $\mathrm{mg} / \mathrm{L}$ were found at sampling station 4 . This result implied that the water quality in these sampling stations had slightly declined, which can be attributed to dissolved and undissolved organic matter. These organic matters can encourage the growth of aerobic microorganisms that use up the DO from the river for their metabolism.

This study also noted that at the other sampling stations $5-8$, the DO in the river had consistently increased from 2002 to 2009 . These values were observed to be above the minimum level of DO (5.0 $\mathrm{mg} / \mathrm{L}$ ) for class $\mathrm{C}$ water quality according to the DENR Administrative Order (DAO) 34. This shows improvement in the water quality within these sampling stations. All but two stations show water quality levels at level B. The remaining two stations, however, indicate a lower quality level at level $\mathrm{C}$. This is a considerable improvement from the initial level D quality of water in the river at some stations.

Data show that except for station samples 2 and 3, all station samples decreased $\mathrm{pH}$ from 2002, 2006, and 2009. This decreasing trend indicates that the Naga river's water is becoming acidic with $\mathrm{pH}$ values lower than $7(\mathrm{pH}<7)$. 
Furthermore, total suspended solids (TSS), stations 1 and 2 increased from 2006 to 2009 while all other sampling stations had a decreased TSS level. The average mean of temperature levels in all the stations falls within the standard criteria of $3^{\circ} \mathrm{C}$, which means that the river can still allow growth and propagation of aquatic species.

In terms of aquatic life in the river, the respondents observe the dwindling supply of fish for their daily consumption. According to them, the fish species that can be found in the Naga river includes talusog/snakehead murrel (Chiana strata), puyo/climbing perch (Arabas testudineus), and tilapia

Figure 1. Impact Flow Diagram of the of Households and Business Activities on the Naga River.

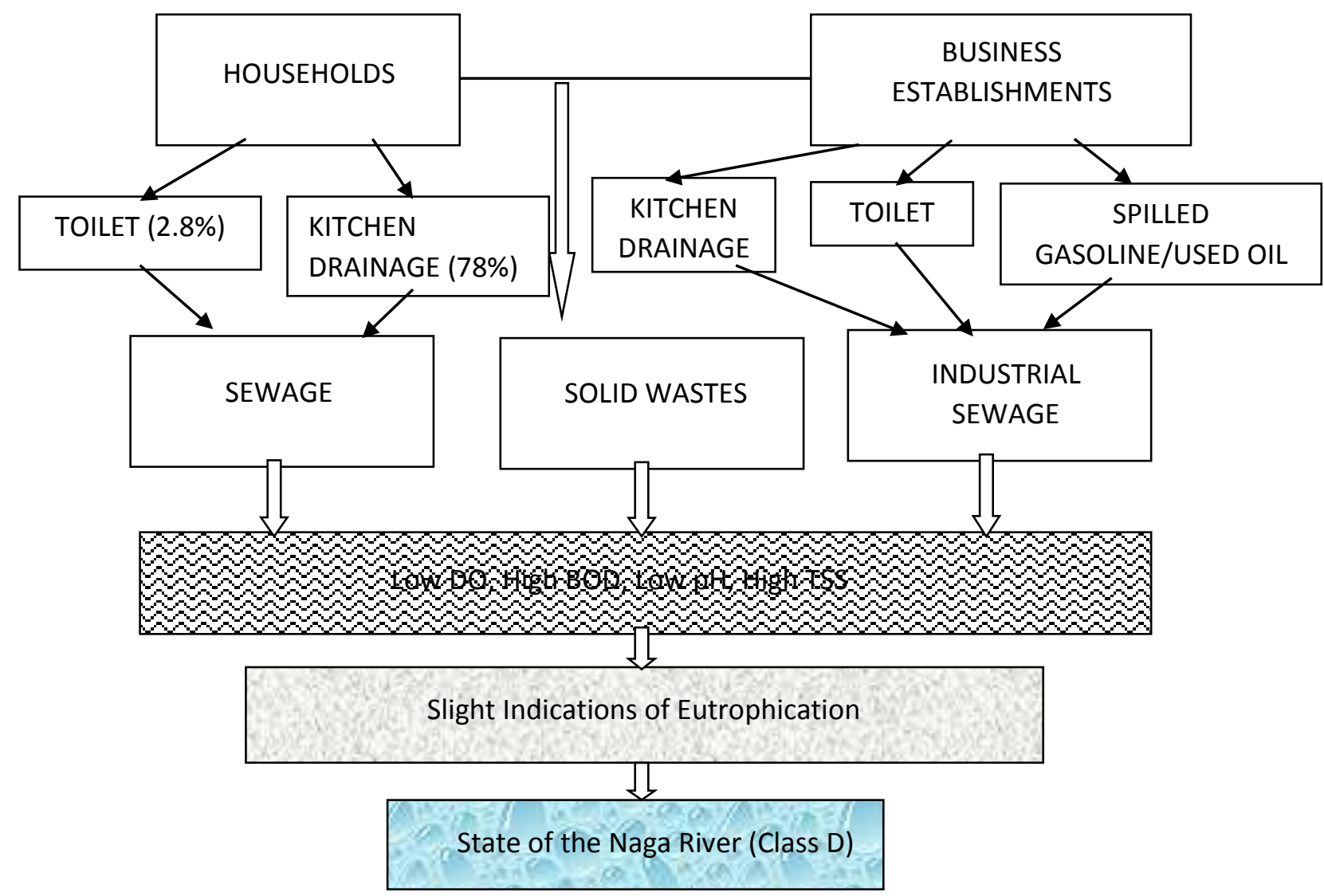

(Oreochromis niloticus/Tilapia nilotica). These are the most abundant species in the 11 riverside barangays closely followed by karpa (Aristichthys nobilis) and bakla (Glossogobius giuris). The species which can only be found in barangay Balatas and Sabang were clams (Corbicula manilensis) and white shrimps (Penaeus vannamei). According to the study, other forms of aquatic life thrive in the Naga river. These are the planktons or plants that supply dissolve oxygen in the water.

\section{Relations of Waste Management Practices to Water Quality and Biological Integrity}

Based on the data above, it can be said that waste management practices of households along Naga river substantially affected its water quality. These indications are manifested in the mid-stream section (sampling station 4) of the Naga river where it is highly residential and commercial in terms of land use. The practice of throwing solid waste and discharging liquid waste in the river enriched its waters with organic and inorganic materials increasing the BOD level. This coincides with the assertion of Orozco (2007) that the primary source of pollution within the river comes from the residential and commercial/business areas in the form of liquid waste. The BOD increases further down the river, with the lowest levels in its headwaters and highest in residential and commercial areas.

On the other hand, the decreasing $\mathrm{pH}$ of water in the Naga river had resulted in the dwindling population and aquatic organisms' growth in the river. A lower $\mathrm{pH}$ value constrains most aquatic organisms' lives since $\mathrm{pH}$ level 8.0 is ideal for aquatic life, while bacteria can survive in $\mathrm{pH}$ levels as low as 2.0. (NASA, n.d.).
Vanderlugt (2007) cited that much of river acidification is the direct result of human pollution. Other than household wastes, pollution from accidental spills, agricultural run-off and sewer overflows can also change the pH (Nkwocha, E. E., et al., 2011).

The comparative data of 2002 - 2006 indicate a trend of improvement in the Naga river's water quality in terms of other parameters. However, there is still observable deterioration of water quality, which can be attributed to the continued practice of the households of throwing and discharging $34 \%$ and $78 \%$ of their solid and liquid wastes respectively directly into the river. In this period, water quality is classified as Class $\mathrm{C}$ at six sampling stations $(1,2,3,6,7 \& 8)$ and Class $\mathrm{D}$ at sampling stations 4 and 5. According to the DENR Administrative Order No.34, class $\mathrm{C}$ is suited for propagation and growth of fish and other aquatic resources; recreation, e.g. boatings; and manufacturing processes. Simultaneously, class D is suited to agriculture, irrigation, livestock, watering, and cooling. 


\section{CONCLUSION}

The present study has documented that the urban environment specifically its practices relating to waste disposal is responsible for the degradation of natural resources. Naga river became a catch basin of both solid and liquid wastes primarily from the hundreds of households located along its banks. This contributed to the pollution of the river affecting its water quality and biological integrity. The study also revealed that the size of built up areas and the household population along the Naga river is not necessarily proportional. It was land usage and the large the number of household population along the Naga river was found to have higher adverse impacts on the water quality and current state of the Naga river.

\section{REFERENCES}

1. Bash, J., Berman, C. H., \& Bolton, S. (2001). Effects of turbidity and suspended solids on salmonids. University of Washington Water Center.

2. Bergkamp, G., \& Cross, K. (2006, January). Groundwater and ecosystem services: towards their sustainable use. In Proceedings of the International Symposium on Groundwater Sustainability (pp. 177-193).

3. Brown, J., Mitchell, N., \& Beresford, M. (2005). Protected landscapes: a conservation approach that links nature, culture and community. The Protected Landscape Approach: linking nature, culture and, 3-18.

4. Carpenter, S. (2011). What is a socio-ecological system. BioComplexity Project, Stockholm Resilience Center.

5. Cities Development Initiative for Asia. (2012, June 14). Executive Summary Naga Pre-Feasibility Study - River Revitalization. www.cdia.asia/2012/06/executive-summary-nagapre-feasibility-study-river-revitalization/

6. City Government of Naga (2012). The Naga City Contingency Plan. https://carbonn.org/uploads/tx_carbonndata/Action \%2016\%20-\%20Disaster\%20Mitigations.pdf

7. Cowx, I. G., Almeida, O., Bene, C., Brummet, R., Bush, S., Darwall, W., Pittock, J., \& van Brakel, M. Session 2 Review - Value of River Fisheries. Food and Agriculture Organization of the United Nations.

http://www.fao.org/docrep/007/ad525e/ad525e04.h tm

8. Elcamel, E. T. (2012). Managing Urban Disasters, The Naga City Experience on Mitigation and Planning. Naga: Naga City Disaster Mitigation Project.

http://www.adpc.net/audmp/rllw/themes/th2-ph.pdf

9. Leitmann, J. (1994). Rapid urban environmental assessment: lessons from cities in the developing world. The World Bank.

10. Lenntech. (2018). Why Dissolved Oxygen is Important. (2018).

https://www.lenntech.com/why_the_oxygen_dissolv ed_is_important.htm

11. Murdock, J. N., \& Dodd, W. K. (2006). Large Rivers Eutrophication. Division of Biology,

Kansas State University.

12. Niemeijer, D., \& de Groot, R. S. (2008). A conceptual framework for selecting environmental indicator sets. Ecological indicators, 8(1), 14-25.

13. Nkwocha, E. E., Pat-Mbano, E. C., \& Nnaji, A. O. (2011). Effect of solid waste dump on river water quality: A paradigm in a Nigerian tropical environment. International Journal of Science and Nature, 2(3), 501-507.
14. Pasion, Cathy. (2007). Managing the Naga City River: Where to Go from Here.

15. $\mathrm{pH}$ and Water Quality. (n.d.). http://www.state.ky.us/nrepc/water/ramp/rmph.htm

16. Philippine Fish Species - List of Common Fish in the Philippines. (2011, May 27). http://philfoodie.blogspot.com/2011/05/philippinefish.html.

17. River Water Quality. (n.d.). http://homepage.eircom.net/ mtstmichaels/MSMWater2000/MSM-Riverwaterquality.html

18. Swanwick, C., \& Heritage, S. N. (2002). Landscape character assessment: guidance for England and Scotland. Making sense of place...

19. Tuvendal, M., \& Elmqvist, T. (2011). Ecosystem services linking social and ecological systems: river brownification and the response of downstream stakeholders. Ecology and Society, 16(4).

20. USAID. (2006). Rapid Socio Ecological Assessment of the Okavango River Basin

Communities in Kuando-Kubango Province, Angola.

21. Vanderlught, F. (2007). River Acidification. http://goarticles.com/article/RiverAcidification/650342/

22. Water Quality. http://www.grc.nasa.gov/WWW/K 12/fenlewis/Waterquality.html 